\title{
The History of Formation of Theoretical and Methodological Foundations of the Constructive Analysis of the English Sentence's Structure
}

\author{
Nurova Gulchehra Tishabayevna \\ Samarkand State University
}

\begin{abstract}
The article examines the process of forming the theoretical and methodological foundations of the constructive analysis of the English sentence's structure in the historical retrospective. The article's author analyzes the scientific works of the Uzbek, Russian and Western scientists devoted to this problem and identifies various aspects of their study of the syntax of the English sentence. The article substantiates the thesis that a large number of scientific works are devoted to the mandatory and optional in syntax, the concepts of an elementary syntactic unit and an elementary syntactic structure, which forms the basis of constructive analysis of an English sentence. The author of the article concludes that further researches should be devoted to the comprehensive analysis of the expansion processes of the main and secondary members of a sentence in modern English. It is also necessary to identify the features of complication of the predicate and other members of the sentence, as well as developing recommendations for overcoming the difficulties of translating sentences in modern English and a description of techniques for applying different translation strategies.

Key words: the study of syntax, constructive analysis, the structure of the English sentence, theory and methodology, obligatoriness, optional, elementary syntactic structure, elementary syntactic unit.
\end{abstract}

Article Received: 16th October, 2020; Article Revised: 30th December, 2020; Article Accepted: 08th January, 2021

Introduction. The study of the syntactic structure's features of a language in terms of constructive syntax is very urgent nowadays. Many scientists in the Republic of Uzbekistan and abroad dealt with the problem. Constructive syntax substantially supplements the traditional syntax by analyzing the structure of a sentence in terms of the constructive significance of its constituent parts. It allows describing the syntactic structure of a sentence in a new way and in a relatively simple form. Constructive analysis of the English sentence's structure is necessary to improve the quality of translations from English into other languages; it allows making a critical review of transformational theory and other areas of modern structural linguistics.

Research methods: 1) retrospective analysis of the formation of theoretical and methodological foundations of constructive analysis, the method of comparative linguistic; 2) the method of distributive analysis (classification of linguistic units and the study of their properties based on the distribution (distribution) of the units in question in the speech stream), i.e. based on their compatibility; 3) the method differential analysis (the study of such phenomena in which the states of linguistic units and their properties are continuously changing); 4) induction; 5) deduction; 6) abstraction; 7) forecasting.

Results. The causal relationships of changes in the traditional word order, as well as the degree of fixation and differentiation of models, including the motivation of a certain arrangement, have always been the object of a comprehensive and systematic analysis of linguists. As part of the study of the motivation for these changes, scientists were able to establish that even in languages that have a free word order in a sentence, any modifications affect the meaning of the latter. At the same time, in languages with a fixed word order in a sentence, the possibilities of making communicative 
modifications are significantly limited, which is due to the combat characteristics of these languages. It is due to this circumstance that linguists of different directions pay special attention to their study when characterizing such languages. The history of formation of the theoretical and methodological foundations of the constructive analysis of the structure of a sentence in English as one of the languages with a fixed word order allows us to identify the features of modern syntactic processes in it and the existing possibilities and tendencies to complicate the structure of the sentence. The results of many researches are becoming the basis for the development of modern methods, techniques and tools that allow translators to carry out competent translations, taking into account all the nuances of the English language.

In Uzbek scientific literature many works devoted to the study of syntax are presented. It is especially worth highlighting the substantive works of A. Berdialiev and Kh. Nosirov [1], who analyzed isophase constructions in the Uzbek language, Kh. Mamadov and Berdialiev [2], who made a great contribution to the study of compatibility in phrases, L. Raupova [3], who conducted a sociopragmatic study of polypredicative units in dialogical discourse, Sh. Rakhmatulloev [4], who conducted a comparative analysis of the Uzbek and Russian languages, R. Sayfullaeva and B. Mengliyeva [5], who analyzed syntactic features of the modern Uzbek literary language, A. Safayev [6], who studied the syntax of the Uzbek language, F.S. Ubaeva [7], who studied the coherent parts of speech in the modern Uzbek literary language, F. Khamrokulova [8], who characterized the syntactic relations of the Uzbek and Russian languages, and also in the context of the topic of our research, the doctoral dissertation of N.A. Sadullaeva [9], which is dedicated to identifying the semantic-structural, stylistic and functional features of uncommon and incomplete sentences in the Uzbek and English languages. Based on the results of the study, N.A. Sadullaeva developed the necessary instructions for determining the stylistic features of uncommon and incomplete sentences in the translation process, for an analytical approach to literary texts, for analyzing the use of uncommon and widespread syntactic phenomena in texts, in particular, in journalistic and artistic discourses. At the same time, a serious drawback of this dissertation, in our opinion, is the secondary use of examples from previous dissertation research in this direction, contrary to the rules of scientific research. In general, we note that, unfortunately, in Uzbek historiography there are no dissertations devoted to strategies, methods and techniques for translating syntactic phenomena in Russian and English.

In the Russian scientific literature, the sentences of the English language are studied quite deeply and systematically. Monographs, scientific articles, commentaries of experts and analysts represent it. It seems appropriate to single out the works of N.D. Arutyunova [10], L.S. Barkhudarova [11], G.N. Vorontsova [12], B.A. Ilyish [13], G.G. Pocheptsova [14], A.I. Smirnitsky [15] and others. They reflect the nature and essence of a fixed word order in an English sentence, show the possibilities of expanding the main and secondary members of the sentence, and show how the predicate and other members of the sentence become more complex. In the tutorial by I.P. Ivanova, V.V. Burlakova and G.G. Pocheptsov [16] considered in detail the cases of expansion of the structure of the main members of the sentence. All this formed the theoretical and methodological basis for the subsequent development of our recommendations for overcoming the difficulties of translating modern sentences of the English language into Russian.

In Western scientific literature, this issue is also deeply researched. It seems that the 
works of scientists E.K. Brown, J.E. Miller [17], G. Leech, J. Svartvik [18] and R. Quirk, S. Greenbaum, G. Leech, J. Svartvik [19] in this regard deserve special attention. They present a historical retrospective, a systematic analysis of modifications of the English language sentence's structure is given, the reasons for the changes occurring are revealed, which are actualized in modern examples.

Discussion. An important role in the history of formation of the theoretical and methodological foundations of the constructive analysis of the structure of the English sentence has become the study of the obligation and optionalness in syntax, since this forms the basis for understanding the structure of the sentence and its analysis. It is also necessary to highlight the model-obligatory and optional components in the sentence structure, since the framework of any one model cannot limit them. It seems that this is a common property of the structure syntax underlying the creation of any type of structure. There are different types of propositional and non-propositional models in the language, which are presented in the form of specific constructions; therefore, they necessarily contain model-required and optional components, even if they are not theoretically distinguished as syntactic concepts $[20 ; 118]$.

Numerous studies [21, 22, 23] are also devoted to the communicative function in the English language, which is realized by non-predicative and predicative elementary syntactic units. Elementary syntactic units are the basic units of constructive syntax with a minimum volume. An elementary non-predicative syntactic unit can have only one communicative, and an elementary predicative syntactic unit has several primary predicatives. Elementary predicative syntactic units, which depend on the nature of the primary predicativeness inherent in the syntactic unit: sentences, sentensoids and representative sentences. Structurally nondiscrete non-predicative elementary syntactic units have a universal character from the point of view of constructive syntax. Predicative elementary syntactic units are focused mainly on the typological type of language. The predicative and communicative potentials of the verbal component of predicativity often determine the linguistic status of an elementary syntactic unit.

An elementary syntactic structure is phrases that are not a communicative unit, except for an attributive phrase, which appears as a unit of communication and belongs to nominative syntactic structures. Attributive combinations have a reduced proposition; they can be in a communicative focus and have the highest degree of communicative dynamism, which depends on the author's intention or the communicative perspective of the statement or sentence.

The study of the semantic aspect of adjectives, which are the most comprehensive part of speech, is of great importance in the history of the formation of the theoretical and methodological foundations of the constructive analysis of the structure of the English sentence. Definitive constructions with them have a variety of semantic links between their components. In most cases, the adjective carries the main meaning of the attributive phrase, and the name becomes a structural component. The attribute, depending on the syntactic position of the attributive phrase, is able to act as the semantic center of the entire utterance. The above indicates the relevance and expediency of further research on the semantics of linguistic units, starting with the elementary syntactic structure, which is a word combination $[24 ; 353]$.

Conclusions. The problem of forming the theoretical and methodological foundations of the constructive analysis of the structure of the English sentence 
degree is very relevant in modern linguistics. At the same time, the scientific community presents an insufficient number of works covering this topic. In particular, a comprehensive analysis of the expansion processes of the main and secondary members of the sentence in modern English has not been carried out, and the features of the complication of the predicate and other members of the sentence have not been identified, there are

\section{References}

[1] Бердиалиев А., Носиров Х. Узбек тилида изофали конструкциялар // УТА. 1973. № 3. С. 34-42.

[2] Мамадов Х., Бердиалиев А. Суз бирикмаларида мослашув борми? // Узбек тили ва адабиети. 1973. № 3. С. 43-54.

[3] Раупова Л. Диалогик дискурсдаги полипредикатив бирликларнинг социопрагматик тадқиқи: филол.фанлари доктори...дисс.автореф. Т.:, 2012. 165 c.

[4] Рахматуллоев Ш. Узбек ва рус тилларини киёслаш. - Тошкент: Узбекистан, 1953. 270 с.

[5] Сайфуллаева Р., Менглиев Б. Хозирги ўзбек адабий тили. Синтаксис. Т.: ЎзМУ, 2006. 312 с.

[6] Сафаев А. Исследование по синтаксису узбекского языка. Ташкент: Фан, 1965.

[7] Убаева Ф.С. Хозирги замон ўзбек адабий тилида гапнинг уюшиқ бош бўлаклари. Филол. фанлари номзоди ...дисс. - Самарқанд: 1959. $158 \mathrm{c}$.

[8] Хамрокулов

$\Phi$.

Лингвоспецифические

характерности синтаксических связей русского и узбекского языков // Ученые записки Худжандского государственного университета им. академика Б. Гафурова. Гуманитарные науки. 2010. № 2 (22). C. 55-65. practically no illustrations of the theory on specific examples of relevant publicistic materials. In further research, it seems appropriate to concentrate on the development of recommendations for overcoming the difficulties of translating English sentences into other languages, in particular, into Russian, and on describing the techniques for applying different translation strategies.

[9] Садуллаева Н.А. Нераспространенные и распространенные синтаксические явления в узбекском и английском языках. Автореф. докт. дисс...Ташкент, 2020. 40 с.

[10] Арутюнова Н.Д. Предложение и его смысл. М.: Наука, 1976. 382 с.

[11] Бархударов Л.С. Структура простого предложения современного английского языка. М.: Высш. школа, 1966. 367 с.

[12] Воронцова Г.Н. Очерки по грамматике английского языка. М.: Изд-во лит. на иностр. языке, 1960. $410 \mathrm{c}$.

[13] Ильиш Б.А. Строй современного английского языка. М.: Наука, 1948. $290 \mathrm{c}$.

[14] Почепцов Г.Г. Конструктивный анализ структуры предложения. Киев: Вища школа, 1971. 373 с.

[15] Смирницкий А.И. Синтаксис английского языка. М.: Изд-во лит. на иностр. языке, 1957.342 с.

[16] Иванова И.П., Бурлакова В.В., Почепцов Г.Г. Теоретическая грамматика современного английского языка: Учебник. М.: Высшая школа, 1981. 285 с.

[17] Brown, E.K., Miller, J.E. Syntax: A Linguistic Introduction to Sentence Structure. London, Hutchinson, 2017. 364 p.

[18] Leech, G., Svartvik, J. A Communicative Grammar of 
English. London, Longman, 2016. $312 \mathrm{p}$.

[19] Quirk, R., Greenbaum, S., Leech, G., Svartvik, J. A Comprehensive Grammar of the English Language. London, Longman, 2015. 427 p.

[20] Шаумян К.С. Теоретические основы Трансформационной грамматики. В сб.: Новое в лингвистике, вып. II, М.: Мысль, $1962.672 \mathrm{c}$.

[21] Яшина Е. Репрезентанты английских предложений и клауз: автореф. дис. ... канд. филол. наук. Саратов: Наука, 2004. 43 с.

[22] Gardiner A. The Theory of Speech and Language. Oxford, 1969. $436 \mathrm{p}$.

[23] Чеснокова Л.Д. Грамматическая сочетаемость слов в простом предложении и факторы, обусловливающие ее. В сб.: Сочетаемость языковых единиц. М.: Изд-во РГУ, 2003. 371 с.

[24] Хужанова М.И. Совершенствование обучения иностранным языкам - веление времени // Молодой ученый. 2014. № 11 (70). C. 349-358.

\section{References}

[1] Berdialiev A., Nosirov X. Uzbek tilida isofali konstruklar [Uzbek tilida izofali konstrukciyalar] // UTA. 1973. No. 3. S. 34-42.

[2] Mamadov X., Berdialiev A. Suz birikmalarida moslashuv bormi? [Suz birikmalarida moslashuv bormi?] // Uzbek tili va adabieti. 1973. No. 3. S. 43-54.

[3] Raupova L. Dialogue discoursedagi polypredicative birliklarning sociopragmatist tadқіқі [Dialogik diskursdagi polipredikativ birliklarning sociopragmatik tаdқіқі]: philol.fanlari doctor ... dissertation author. Tashkent: 2012.165 p.

[4] Rakhmatulloev Sh. Uzbek va rus tillarini kiyoslash [Uzbek va rus tillarini kiyoslash]. Tashkent: Uzbekistan, 1953.270 p.
[5] Sayfullaeva R., Mengliev B. Xozirgi y̌zbek adabiy tili [Xozirgi y̌zbek adabiy tili]. Syntax. Tashkent: UzMU, 2006.312 p.

[6] Safayev A. Research on the syntax of the Uzbek language [Issledovanie po sintaksisu uzbekskogo yazyka]. Tashkent: Fan, 1965.

[7] Ubaeva F.S. Xozirgi zamon y̌zbek adabiy tilida happing uуushiқ bosh by̆laklari [Xozirgi zamon y̆zbek adabiy tilida happing uyushiқ bosh by̆laklari]. Filol. fanlari nomzodi ... diss. - Samaraand: 1959.158 s.

[8] Khamrokulov F. Linguospecific characteristics of syntactic relations between the Russian and Uzbek languages [Lingvospecificheskie harakternosti sintaksicheskih svyazej russkogo i uzbekskogo yazykov] // Scientific notes of the Khujand State University, academician B. Gafurov. Humanitarian sciences. 2010. No. 2 (22). S. 55-65.

[9] Sadullaeva N.A. Uncommon and widespread syntactic phenomena in the Uzbek and English languages [Nerasprostranennye i rasprostranennye sintaksicheskie yavleniya $\mathrm{v}$ uzbekskom i anglijskom yazykah]. Author's abstract. doct. diss ... Tashkent, 2020. $40 \mathrm{p}$.

[10] Arutyunova N.D. The proposal and its meaning [Predlozhenie i ego smysl]. Moscow: Nauka, 1976.382 p.

[11] Barkhudarov L.S. The structure of a simple sentence in modern English [Struktura prostogo predlozheniya sovremennogo anglijskogo yazyka]. M.: Higher. school, 1966.367 p.

[12] Vorontsova G.N. Essays on the grammar of the English language [Ocherki po grammatike anglijskogo yazyka]. M.: Publishing house lit. foreign language, $1960.410 \mathrm{p}$.

[13] Ilyish B.A. The structure of modern English. Moscow [Stroj sovremennogo anglijskogo yazyka]: Nauka, 1948.290 p. 
[14] Pocheptsov G.G. Constructive analysis of the sentence structure [Konstruktivnyj analiz struktury predlozheniya]. Kiev: Vischa school, $1971.373 \mathrm{p}$.

[15] Smirnitsky A.I. English syntax [Sintaksis anglijskogo yazyka]. M.: Publishing house lit. to foreign language, $1957.342 \mathrm{p}$.

[16] Ivanova I.P., Burlakova V.V., Pocheptsov G.G. Theoretical grammar of modern English [Teoreticheskaya grammatika sovremennogo anglijskogo yazyka]: Textbook. M.: Higher school, $1981.285 \mathrm{p}$.

[17] Brown, E.K., Miller, J.E. Syntax: A Linguistic Introduction to Sentence Structure. London, Hutchinson, 2017. 364 p.

[18] Leech, G., Svartvik, J. A Communicative Grammar of English. London, Longman, 2016. $312 \mathrm{p}$.

[19] Quirk, R., Greenbaum, S., Leech, G., Svartvik, J. A Comprehensive Grammar of the English Language. London, Longman, 2015. 427 p.

[20] Shaumyan K.S. Theoretical Foundations of Transformational

[25] 58
Grammar [Teoreticheskiye osnovy Transformatsionnoy grammatiki]. In collection: New in linguistics, no. II, Moscow: Mysl', 1962. 672 p.

[21] Yashina E. Representatives of English sentences and clauses [Reprezentanty angliyskikh predlozheniy i klauz]: author. dis. ... Cand. philol. sciences. Saratov: Nauka, 2004.43 p.

[22] Gardiner A. The Theory of Speech and Language. Oxford, $1969.436 \mathrm{p}$.

[23] Chesnokova L. D. The grammatical combination of words in a simple sentence and the factors that determine it [Grammaticheskaya sochetayemost' slov $\mathrm{v}$ prostom predlozhenii i faktory, obuslovlivayushchiye yeye]. In collection: Compatibility of language units. M.: Publishing house of the Russian State University, 2003.371 p.

[24] Khuzhanova M.I. Improvement of teaching foreign languages - the imperative of the time [Sovershenstvovaniye obucheniya inostrannym yazykam - veleniye vremeni] // Young scientist. 2014. No. $11 \quad$ (70). $\quad$ S. $349-3$ 